ISSN (O) 2589-8779 | (P) 2589-8760

\title{
To Determine a Quality from Visum ET Repertum Needs a Living Victim in Rsud Posea Since 1st January 2015 Till 31st December 2018.
}

Petrus, Asan ${ }^{1^{*}} \mid$ Simatupang, Panusunan ${ }^{2}$

${ }^{1}$ Department of Forenic and Medicolegal

2 Medical Faculty of University North Sumatera

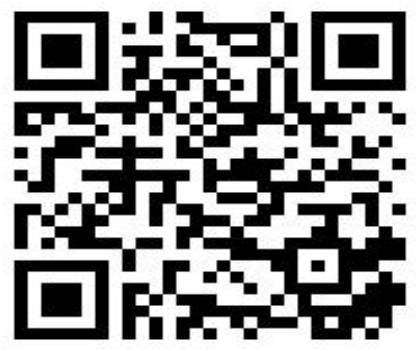

\begin{abstract}
:
Background : Visum et repertum (VeR) as evidence plays a role in the process of proving a criminal case and is expected to provide sufficient information for law enforcers, especially judges in making court decisions, for this purpose a good quality VeR is needed.

Methods : This study is an observational study with a descriptive analytic approach to post mortem data for injuries of living victims in Porsea Regional Hospital for the period January 1, 2015 to December 31, 2018, using a scoring tool from Herkutanto to 13 variables in visum et repertum of injuries to living victims. . The sample was selected by total sampling method.
\end{abstract}

Results: The total number of cases examined by doctors as evidenced by the VeR letter was 17 cases. The quality of the VeR injury to the preliminary section is $100 \%$ (the quality is good). The quality of the VeR injury in the news section is $51.56 \%$ (moderate quality). The quality of the VeR injury to the conclusion is $45.5 \%$ (the quality is not good). The quality of the VER of the injuries in general was $51.54 \%$ (moderate quality).

Conclusion: Based on the results of this study, the post-mortem made by doctors at Porsea Hospital is not good, it is still in the moderate category, especially the news and conclusions section, this is in accordance with what is stated in the Regulation of the Indonesian Medical Council No. 11 of 2012 and the results of previous studies.

Keywords: Visum et Repertum, injury, quality of the injury

\section{1 | INTRODUCTION}

$\mathrm{N}$ owadays, we hear a lot and even we can see crime scenes (cases) that are not only involving material things but people's life. In the course of tracing these cases, the police con- duct an investigation till end up in the court. In process of investigate a people's life normally an investigator request help from the professional such as a doctor called visum et repertum. The doctor's assistance to the legal community (investigator, lawyer and judges) absolutely necessary in this case is to 

POSEA SINCE 1ST JANUARY 2015 TILL 31ST DECEMBER 2018.

examine the victim for the process of Visum et Repertum (VeR) or normally only called 'visum'. A good cooperation between poice/investigator and doctor / professional forensic has been built for long time ago and continiously working together to uphold a justic for noth victims and suspects. Visum is a plural from Visa, means that its seen and repertum is a plural of Repere, which means found, thus the meaning of VeR is seen and found. From Government Hospital even private sector till a community center, there are hundred every month tht need to be examined by a doctor to make a visum that requested from investigator, and the most common is visum for injury because of fights, torture, and traffic accidents, then violation of decency or rape, and foolowed by mortuary visum. By making Visum et repertum report on the result of examinations of victims, both live and dead, is one of the services provided by general doctor or even a forensic doctor / professional forensic that can help a law enforcer to uphold a justice. Visum et repertum is a written statement/report from a general doctor ( from their capacity as professional) or a professional forensic doctor that requested by offical authorize law about what they seen and found from the object that being examined (the body of the victim, both living and dead or part of human body) by remembering the oath and promise when receiving the position. Visum et Repertum is meant one of the evidences of justice which is if the process to make the visum is incorrect or lacking of quality the the role of visum in the process of proving a criminal case against the health and life of human being is not achieved which the judges will have a difficulty to making the decision. Based on Medical Council Regulation in Indonesia no 11 year of 2012 about the Standart Compentency doctor in Indonesia (SCDI) page 29 about the related issues of doctor's profession point 28 that stated a doctor refused and / or not make Visum et repertum according to scientific starndars that should be compulsory. This regulation is a feedback of general description of health services problem in the field, especially in services to help patient to enforce the law that related to crime they experienced. Beside that, based on the research from Herkutanto in 19992000 to 977 life victims of VeR in 38 Hospital in Jakarta that most of the VeR is still in low quality
(Herkutanto, 2005). Based on that, the researcher would like to find out whether if it's true that visum that conduct in the field that make by the general doctors in some of hospital still not have a good quality and even have not make any research about the quality of visum et repertm in RSUD Porsea, thus, the researcher interested to know the quality VeR in RSUD Porsea period of 1st January 2015 till 31 st December 2018.

\section{1 | Preface}

The introduction words itself does not exist, what Pro Justisia said, doctors must realize that all letters are only valid in court if they are made on stamped paper and this will make it difficult for doctors if every

visum they did must use stamped paper. Guided by the postal regulations, so if the doctor writes projustisia at the top of the visum letter then it is already same with stamped paper. By writing Pro- Justisia on the upper left of the visum letter is more interpreted that the makers and users of the visum are initially aware that the report is for the sake of justice (ProJustitia).

\subsection{Preliminary:}

The preliminary words in this section does not exist. This section contains 3 main components, namely doctors who examined the victims, investigators who ask to be examined and victims / suspects to be examined. This section contains about who is checking, place / agency to do the inspection, day, date and time of the inspection. why it was being examined, and whose request the visum was made. Name of investigator, agency, visum's letter number, $\&$ date of request.

Supplementary information The online version of this article (https://doi.org/10.15520/jcmro.v3i09.33 5) contains supplementary material, which is available to authorized users.

Corresponding Author: Petrus, Asan Department of Forenic and Medicolegal Email: asanpetrus95@gmail.com 


\section{3 | Inspection/Inspection Results:}

This section is titled the results of the examination, and not the results of external examinations as often written by students. The most important part of the visum actually are in this section, because what doctors seen and found is recorded and as a substitute for evidence in the form of a report called Visum et Repertum. In this section, the doctor writes the type of injury, the area / region where the injury was found, the size of the injury, the distance of the injury from the midline of the body and / or from a specific anatomical point.

\section{4 | Conclusion:}

This section is titled of "conclusions". For visum users, this is the most important part, because it is expected that doctors can conclude the abnormalities that occur in victims according to their expertise. The injured victims need to explain about the type of injury, the type of violence, the causal relationship of the disorder, about the degree of qualification of the injury, how long the victim need to be treated and the hope of recovery.

\section{5 | Closing:}

This section has no title and contains standard sentences. The closing section is marked with the sentence" Thus the Visum et Repertum I made was actually based on my knowledge and by remembering the oath in accordance with the Criminal Procedure Code. This section reminds doctors that the report is made honestly, not added or reduced and without being influenced by any party, this report is also based on the best knowledge and report the results of examinations related to the case, while those not related to the case will remain as a medical secret. This report is also made according to procedures in the criminal procedure code, for judicial purposes.

\section{2 | RESEARCH METHODS}

This study was an observational study with a descriptive analytic approach to Visum et Repertum data on the injuries of living victims in Porsea Regional Hospital from January 1, 2015 to December 31, 2018. This research was conducted at the Porsea Regional General Hospital, Toba Samosir Regency. starting from April to May 2019. The population in this study is the Visum et Repertum that needs a life victim which made by doctors in the Emergency unit of the Porsea Regional General Hospital from January 1, 2015 to December 31, 2018. The sample used in this study is the total from sampling population.

Data collected for the variable elements of the VeR were obtained from secondary data, which is the VeR document for the period of January 1, 2015 to December 31, 2018. The results of the study are presented in table form. The data analysis of the variables of the visum elements was carried out using the Herkutanto's scoring method for the 13 elements of the visum. The elements assessed were given a score of 0,1 , and 2 with the highest score of 2 , while the descriptive analysis was performed on the data of injured victims, type of violence, degree of injury and the quality of VeR.

\section{3 | RESULTS AND DISCUSSION}

Based on the results of research conducted in April to May 2019 in Porsea Regional Hospital, Toba Samosir Regency, the number of forensic medical services for injuries with life victims as evidenced in the document visum et repertum during the period 1 January 2015 to 31 December 2018 there were 17 cases.

\subsection{The Quality of VeR needs Preliminary Part.}

The quality of VeR needs the preliminary in the Porsea District Hospital from 1st January 2015 to 31 st December 2018 which is presented in Table 1.

The quality value of the preliminary part $=\left(2.0 \times \frac{1}{2}\right.$ ) $\mathrm{x} 100 \%=100 \%$ Based on the results of this study conducted on the VeR to the life victims in Porsea Regional Hospital from January 1, 2015 to December 31,2018 , the quality of the preliminary VeR was $100 \%$, which means that the quality is good. 
TO DETERMINE A QUALITY FROM VISUM ET REPERTUM NEEDS A LIVING VICTIM IN RSUD POSEA SINCE 1ST JANUARY 2015 TILL 31ST DECEMBER 2018.

TABLE 1: Quality of VeR needs preliminary part in the Porsea Regional Hospital from January 1 2015to December 31, 2018

\begin{tabular}{lll} 
VeR Structure & $\begin{array}{l}\text { Variable } \\
\text { observed }\end{array}$ & $\begin{array}{l}\text { Average } \\
\text { Score }\end{array}$ \\
Preface & $\begin{array}{l}\text { Place of } \\
\text { examination }\end{array}$ & 2 \\
& $\begin{array}{l}\text { Time of } \\
\text { examination }\end{array}$ & 2 \\
& $\begin{array}{l}\text { Patients data } \\
\text { Investigator }\end{array}$ & 2 \\
Doctor examiner & 2 \\
Average total & data & 2 \\
score & & \\
\hline
\end{tabular}

\subsection{The Quality of The VeR Needs The Reporting section}

The quality of the VeR needs the reporting section the Porsea District Hospital for the period of January 1, 2015 to December 31, 2018 is presented in Table 2.

TABLE 2: VeR quality of the reporting coverage in PorseaRegional Hospitalon January 1, 2015 to December 31, 2018.

$\begin{array}{lll}\text { VeR Structure } & \text { Variable observed } & \begin{array}{l}\text { Average } \\ \text { Score }\end{array} \\ & \text { Anamnesis } & 0.0 \\ & \text { Vital Sign } & 1.0 \\ & \text { Wound Location } & 2.0 \\ \text { Report } & \text { Wound } & 1.18 \\ & \text { charateristics } & \\ & \text { Wound size } & 2.0 \\ & \text { Therapy and } & 0.0\end{array}$

Average total score 1.03

The quality of reporting coverage $=(1.03 \times 5 / 10) \times$ $100 \%=51.56 \%$

Based on the results of this study conducted on the VeR for life victim in Porsea Regional Hospital from January 1, 2015 to December 31, 2018 it was found that the quality of reporting coverage VeR was $51.56 \%$ which means the quality was moderate.

\section{3 | The Quality of The VeR Injured in a Conclusion Part}

Thequalityofthe VeR injured in the Conclusion part at the Porsea District Hospital for the period of January 1, 2015 to December 31, 2018 is presented in Table 3.

TABLE 3: Quality of VeR the Conclusions part of Porsea District Hospital for the period of 1 January 2015 to 31 December 2018

$\begin{array}{llll}\text { VeR } & \text { Average } & \begin{array}{l}\text { Qual- } \\ \text { ity }\end{array} & \begin{array}{l}\text { Average } \\ \text { Score }\end{array} \\ \text { Structure } & \text { score } & 1 & 2.00 \\ \text { Preface } & 2.00 & 5 & 5.15 \\ \text { Report } & 1.03 & 8 & 7.28 \\ \text { Conclusion } & 0.91 & 8.43 \\ \text { Total } & & & 14.4\end{array}$

The value of the quality of Conclusion part $=(0.91$ x $8 / 16) \times 100 \%=45.5 \%$ Based on the results of this study conducted on the VeR of injured life victims in Porsea Regional Hospital from January 1, 2015 to December 31, 2018 it was found that the conclusion of the quality of VeR was $45.5 \%$, which means that the quality was not good enough.

\section{4 | The Quality of Ver Injury}

The quality of injured VeR in Porsea District Hospital from January 1, 2015 to December 31, 2018 is presented in Table 4.

TABLE 4: Quality of injured VER in Porsea District Hospital from 1 January 2015 to 31 December 2018.

VeR Variable observed Aver-

Structure age

Score

Conclusion Wound Charateristic and 1.82 violence Classification Wound qualification $\quad 00$

Average Total score

0.91

Quality value of $\mathrm{VeR}=(14.43 / 28) \times 100 \%=$ $51.54 \%$. Based on the results of this study conducted 
on VeRs of injured life victim in Porsea Regional Hospital from January 1, 2015 to December 31, 2018, the quality of injured VeRs was $51.54 \%$, which means that the quality of injured visum was moderate. From the results of this study, that the writing of injured visum et repertum in moderate quality at Porsea Regional Hospital, these results are relatively the same as what is stated in the Indonesian Medical Council regulation no. 11 of 2012 about the Standard Competency Doctor Indonesia (SKDI) on page 29 point 28 which states that doctors have not been able to make visum et repertum in accordance with scientific standards that should be done (standard 4-A), and are relatively similar to the results of previous studies by Herkutanto, Fadlan Tri Ramadhan, Dedi Afandi, Laode Burhanuddin Mursali, but are the conditions of visum et repertum in Porsea Regional Hospital is sufficient to represent the real Indonesia and conditions for all Indonesia. certainly requires the same research at other health institution.

\section{4 | CONCLUSIONS AND SUGGESTIONS:}

Based on research results obtained from Visum et Repertum data in Porsea Regional Hospital January 1, 2015 until December 31, 2018, it can be concluded:

a. The number of injury cases with life victims that has been examined by doctors as evidenced by Visum et Repertum letter in the Porsea Regional Hospital from January 1, 2015 to December 31, 2018 were 17 cases.

b. The quality of the Visum et Repertum injury for life victims in Porsea Regional Hospital from January 1, 2015 to December 31, 2018, obtained the quality of the preliminary injury of VeR at $100 \%$, which means that the quality is good.

c. The quality of the injured in VeR of life victims in Porsea Regional Hospital from January 1, 2015 to December 31, 2018 showed that the quality of injured report coverage of VeR was $51.56 \%$, which means that the quality was moderate.

d. The quality of injured VeR for life victims in Porsea Regional Hospital from January 12015 to 31
December 2018 showed that the quality of injured VeR (1) in Conclusion was $45.5 \%$, which means that the quality was not good.

e. The quality of injured life victims of VeR at Porsea Regional Hospital from January 12015 to December 31,2018 obtained the quality of injured VeR at $51.54 \%$ which means that the quality is moderate.

\section{5 | SUGGESTION}

Based on the results of the study above, the authors suggest a number of things as a contribution to hospital leaders so that in the future the quality of the Visum et Repertum can be issued better, which is:

1. Hospital leaders must be aware that Visum et Repertum is a document of legal evidence that is a substitute for goods evidence, which must provide information explaining an event (the process of proving a criminal case) that helps investigators and court judges in making decisions of court. The role of visum et repertum thus its only found in visum et repertum with good quality.

2. To be able to make a good visum et repertum, the authors suggest that training / workshops to be given for Emergency Unit at Porsea Regional Hospital regards on the making of a Visum et Repertum especially regarding the injury VeR.

3. To make suggestions to be carried out for training / workshops to emergency unit doctors in Porsea Regional Hospital regarding the preparation of the Visun et Repertum, the writer is ready to help as a guest speaker/informant. $(1,2)(3,4)(5,6)(7-10)$

\section{REFERENCES}

1. Amir A. 2005. Rangkaian Ilmu Kedokteran Forensik. Bagian ilmu kedokteran forensik dan medikolegal FK-USU, Edisi Kedua, Cetakan pertama, Ramadhan: Medan.

2. Budiyanto.A Widiatmaka.W.Atmaja.DS, dkk, 1997, Ilmu Kedokteran Forensik , Bagian Kedokteran FK-UI, Jakarta, Edisi pertama, cetakan pertama, Jakarta 
3. Dahlan. S. 2000, Ilmu Kedokteran Forensik Pedoman bagi Dokter dan Penegak Hukum, Cetakan Ketiga Universitas Diponegoro, Semarang.

4. Hamdani N, 1971, Himpunan kuliah-kuliah ilmu kedokteran kehakiman, Bagian ilmu kedokteran kehakiman fakultas kedokteran Universitas Airlangga, Cetakan pertama, Surabaya.

5. Hamdani, N. 1992. Ilmu Kedokteran Kehakiman :KualifikasiLuka. Penerbit PT Gramedia Pustaka Utama. Jakarta.

6. Kitab Undang-Undang Hukum Pidana (KUHP) dan Kitab Undang-Undang Hukum Acara Pidana (KUHAP) beserta penjelasannya, Cetakan IV, Citra Umbara, Bandung, 2009.

7. Lamintang, P.A.F.Drs.S.H dan Lamintang, Theo, SH. 2010, Delik-delik khusus kejahatan terhadap nyawa, tubuh dan kesehatan.edisi kedua, Cetakan pertama, Sinar Grafika, Jakarta
8. Mertodidjojo MS, 1953, Buku penuntun ilmu dokter kehakiman, Lembaga pathologis dan kamar mayat pusat RSUP Surabaya, Edisi pertama, Cetakan kedua, Surabaya.

9. Munim Idries, Legowo A, 2008, Penerapan Ilmu Kedokteran Forensik dalam proses penyidikan, Edisi Revisi, Cetakan I, Sagung Seto, Jakarta.

10. Peraturan Konsil Kedokteran Indonesia no.11 tahun 2012 tentang Standar Kompetensi Dokter Indonesia .

How to cite this article: Asan P., Panusunan S. To Determine a Quality from Visum ET Repertum Needs a Living Victim in Rsud Posea Since 1st January 2015 Till 31st December 2018. Journal of Current Medical Research and Opinion. 2020;625-630. https://doi.or g/10.15520/jcmro.v3i09.335 